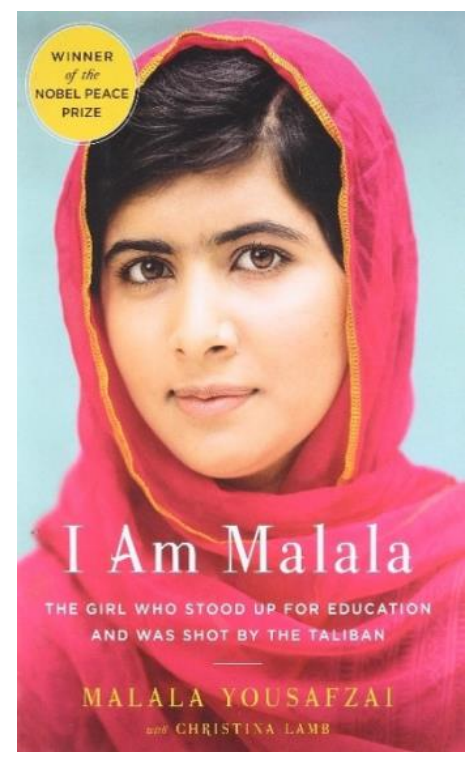

Malala Yousafzai with Christina Lamb. (2013). I Am Malala: The Girl Who Stood Up for Education and Was Shot by the Taliban. Little, Brown \& Company. 327 pages. ISBN-10: 0316322407

\title{
Shot but Not Silenced: I Am Malala
}

\author{
Alyssa Sanabria ${ }^{1}$ \\ Florida Gulf Coast University, USA
}

\begin{abstract}
I am Malala: A Girl who Stood Up for Education and was Shot by the Taliban is a compelling autobiography about a 14-yearold girl's campaign for girls' right to education within an oppressive society. The entire book is written from Malala's perspective, each chapter allows the reader to become immersed within the text and invested within human rights oppression. Malala's story seeks to bring awareness to the injustices within education for young girls and women as well as emphasize the power of education. Malala challenges the reader to dig deeper into the oppressiveness and truly examine the value of education.
\end{abstract}

Keywords: girls' education, human rights, taliban, women's rights.

I am Malala: A Girl who Stood Up for Education and was Shot by the Taliban, written by Mala Yousafzai and Christina Lamb, immediately begins by shedding light on human rights issues being faced daily by girls living in Pakistan. This book was written from the perspective of Malala as she takes us on a journey through what life is like in the Swat Valley of Pakistan for a young girl longing to continue her education. This autobiography is written in a five-part structure with a total of 25 chapters. Each chapter walks the reader through the story of her fight for not only girls' education but also the struggle and fear they endured due to uprooting their family because of global terrorism. Malala's story is one of bravery, honesty, and fight. From the day she was born, she was different, and her father always knew her culture's shackles would not limit her. Malala loves her family, her faith, and her opportunity to experience education. She fought for education during a time when oppressive political constraints and extremism were terrorizing her village and country. Malala lived to tell a story of victory and determination while providing a platform for those who still do not have the privilege to speak out for themselves.

\footnotetext{
${ }^{1}$ Correspondent Author E-Mail: alsanabria@fgcu.edu
} 


\section{Review}

McCowan (2013) states that education is widely recognized as a human right. However, the nature of this right is still unclear. Nowhere within this definition is there a distinction between gender or identity but rather just the statement of basic human rights. Shah and Shah (2012) identifies the education of girls as a global issue. Many reports and papers, including the UNESCO, reports on gender monitoring and education highlight the intensity of this challenge across the world. Malala was aware that she was fortunate to go to school. Malala's father believed that girls deserved education and was responsible for opening schools for girls to attend. Malala truly looked up to her father and was inspired by his good works within an oppressive society.

The Universal Declaration of Human Rights says that everyone has the right to education (Vasconcelos, 2015). However, for girls and women in Pakistan, their lives are viewed differently from birth. Within her society, Malala acknowledged that girls were not celebrated the way boys were. She possessed a deeper understanding of warped gender roles early on in her life and how they were related to educating girls and women in Pakistan (Yousafzai \& Lamb, 2013). Correspondingly, Malala used this understanding to become a talented speaker and advocate equal education to all. From birth, she knew her father was not the typical Pakistani father. He knew she was special and named her accordingly. As she grew, he continued to be forthright with his views regarding education and women's rights. He was passionate about these things, which led to him opening schools available to girls and boys alike. It is $100 \%$ safe to say that Malala's father helped to spark a flame within her heart regarding education and the rights she had to it as a woman.

In Pakistan, there is social disapproval of women working outside of the home (Jalal, 1991). However, with social, economic, political, and technological changes, there is a place to introduce a new social structure that can facilitate women's gradual movement to the public arena from the confinement of their homes (Jalal, 1991). Pakistan's situation is not the same as Western nations or other developed/developing countries, meaning that no matter which class or region Islamic women belong to, their situation relative to men is one of systemic subordination determined by specific patriarchal forces (Jalal, 1991). Women within this society are supposed to be homemakers and mothers, not well-educated and outspoken. Malala refused to fill this mold of society as she felt she was destined for a different calling (Yousafzai $\&$ Lamb, 2013). Malala's oppression and almost near-death experience were caused by the rise of the Taliban to power and its effect on her beautiful home in Swat Valley.

The Taliban is a patriarchal and terroristic group that attacks girls' schools as part of the long-term strategy to take the society back into the dark ages of ensuring an illiterate society (Chandran, 2008). This strategy only works if fear is created amongst women; hence violence is used to push women away from achieving education or speaking out (Chandran, 2008). Women are beaten, injured, and some even killed, much like the attempt made on Malala, all in efforts to deny education to girls. The Taliban stopped at no cost to instill this fear by bombing schools and forcing operations to cease if they would offer enrollment to girls. If this were not enough to send fear into young women, the Taliban assassinated the female Prime Minister, almost to show a warning to any young woman seeking to progress within society. At the time of this gruesome attack, little 10-year-old Malala, with support from her father, used this as fuel to become more outspoken regarding the heinous terrorism the Taliban was imposing on Pakistan's people.

However, while human rights are a significant component of the story, social justice must not be forgotten. Ensuring that everyone within society has a right to education without being persecuted for it is a type of social justice (Vasconcelos, 2015). Malala had the privilege of having a father who viewed her as more than a "girl" within her society. He had schools that allowed her to be exposed to education and limit society's oppressive nature on her educational 
experience. Malala was free to use her creative thinking and judgment to form opinions regarding life in Pakistan during the Taliban's oppressive times.

Even as times continued to get more dangerous and Swat Valley was taken over, this did not stop Malala from being brave and speaking out. She continued to be the voice and used a pseudonym to continue writing diary entries regarding the education of girls in Pakistan without being revealed. The Taliban found this to be unacceptable; hence she became a target. Malala, at the age of 12, was riding on a school bus home when it was stopped by a man who shot her. Malala was taken to Birmingham in the United Kingdom to recover and receive serious medical attention while people from around the globe waited to see if she would pull through. Malala tells the heart-wrenching story of her mother and father's experience as they were held in Pakistan and could not join her as she underwent medical treatment. While the Pakistani government eventually allowed her family to join her, it was not an easy feat. It was heartwarming to see the amount of support this young girl had from all over the world. The Taliban thought they would extinguish her flame eternally; however, they ignited a wildfire. Malala did not let this near-death experience stop her. Malala was like no other; she was brave then and continues to be brave now. She is an activist and international sensation. Malala continues to speak out regarding girls' education.

\section{Summary}

This book was written for anyone who has a passion for human rights, equal education, or girls' education in oppressive societies. From the moment you open this book, you are taken on a journey from the perspective of a young girl immersed in this society of oppression and terrorism. It is as though Malala is guiding the reader through her life to advance or bring awareness to the travesties caused by the Taliban. This book not only contributes to current literature regarding the education of girls/women in Pakistan, but this book also brings a higher platform thanks to Malala's ability to captivate millions through her story. Her story is inspiring and convincing because her words show the pain and passion she had to endure to fight for her right to be educated. Malala wrote this book to heighten awareness, educate, bring awareness, and provide a platform for the voiceless; this book not only accomplished these goals but also captivates readers' hearts.

\section{References}

Chandran, D. S. (2008). Violence against women in Swat: Why blame only Taliban? IPCS Issue Brief, 97, 1-4. https://www.files.ethz.ch/isn/98731/IB97-Suba-WomenSwat.pdf

Jalal, A. (1991). The convenience of subservience: Women and the state of Pakistan. In D. Kandiyoti (Ed.), Women, Islam and the state (pp. 77-114). Palgrave Macmillan.

McCowan, T. (2013). Education as a human right: Principles for a universal entitlement to learning. Bloomsbury Publishing.

Shah, S., \& Shah, U. (2012). Girl education in rural Pakistan. Revista Internacional de Sociología de la Educación, 1(2), 180-207.

Vasconcelos, C. P. (2015). He named me Malala: Malala's voice, vision, and leadership. The International Journal of Servant Leadership, 11(1), 497-510.

Yousafzai, M., \& Lamb, C. (2013). I am Malala: The girl who stood up for education and was shot by the Taliban. Little, Brown \& Company. 


\section{Notes on Contributor}

Alyssa Sanabria is a doctoral student in the Department of Curriculum, Instruction, and Culture at Florida Gulf Coast University, USA. Her scholarship focuses on multicultural education, diversity and inclusion, human rights, special education, post-secondary transition programs, and behavioral studies. She has taught students with emotional behavioral disorders (EBD) for seven years and is now teaching undergraduate courses within the post-secondary program at Florida Gulf Coast University. Recently, she has transitioned from the local school district to Florida Gulf Coast University and is serving as a Program Coordinator for the Soaring Eagle Academy serving students with intellectual disabilities within post-secondary education. ORCID ID: https://orcid.org/0000-0002-2686-3707 